\title{
THE STATE POLICE POWER IN THE WEST, AND THE RULE OF LAW IN THE CONTEXT OF INTERNATIONAL TERRORISM-A COMPARATIVE PERSPECTIVE
}

\author{
A. Y. Zohny, L. L. M., Ph.D. *
}

This study traces the historical development of the government's police power and the rule of law since its conception by Adam Smith to datepassing by the events of the 9/11/2001 attack on New York's Twin Towers caused by international terrorism midwife by political Islam. In this article, the author asserts that any successful attempts to combat international terrorism by Western Democracies such as the United States, France, England and Germany should be under the United Nations Command and within the parameters of individual freedoms guaranteed in Western Democracies' constitutions, and human rights international humanitarian law. Furthermore, a United Nations convention to define the act of terrorism as an "international crime" rather than a "war" is needed.

INTRODUCTION 665

I. The Rule of LAW \& Policing Challenges in WeStern Democracies AFTER 9/11/2001 669

A. In the USA. 669

B. In France 671

C. In England 672

D. In Germany 672

III. What THE U.S. AND EUROPE SHOULD Do TO CONFRONT POLITICAL

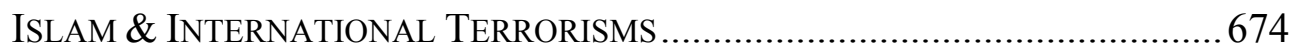
CONCLUSION 676

\section{INTRODUCTION}

The concept and the practice of policing and the rule of law is a part of the western body of literature on the police and the household governance, built by Adam Smith in his famous lectures on justice, police, revenue and arms - a lecture which Adam Smith eventually developed into the wealth of nations. Smith's seminal work was influenced by influential thinkers such as

\footnotetext{
* Associate Professor of Political Science \& International Affairs. Coppin State University, Baltimore Maryland. Chair, Department of Applied Social and Political Sciences. Research fields: Comparative Law, Comparative Political Systems, International Relations, and Middle East Government \& Politics.
} 
Rousseau, Beccaria, Bentham, and even Vattel. ${ }^{1}$

Markus D. Dubber, in his seminal work on "The Police Power, Patriarchy and The Foundations of American Government" (2005), confirmed the theses that government policing should not be limited to enforcement of the law. The Police power "is, and must be from its very nature, incapable of any very exact definition or limitation".

Upon the police power, "the most essential, the most insistent, and always one of the least limitable of the powers of government", hinges nothing less than "the security of social order, the life and health of the citizen, the comfort of an existence in a thickly populated community, the enjoyment of private and social life, and the beneficial use of property".

Also, he advocated that following the violent removal of the old government by a revolution, the new one had to remind its subjects of their duty of obedience ${ }^{2}$. Finally, he pointed out to the difficulties of reforming police and other security agencies during the transition to a new regime and when the revolutionary or founders turn to governors. He argued that

the history of American law and government can profitably be seen as a continuing attempt to resolve, and submerge, the inherent tension between police and law, between public welfare and individual rights, and between heteronomy and autonomy. ${ }^{3}$

He further postulated this difficulty by posing the following questions

of whether police within the limits of law is possible. How can persons capable of autonomy be policed without denying their personhood? How can objects of police remain legal subjects? What role can an essentially hierarchical autocratic mode of governance play in a country where not the householder, but the law is king? How can an essentially heteronymous mode of governance comply with the basic principles of legal legitimacy, and autonomy? ${ }^{4}$

The main research questions in this study are (1) What is police power within the context of the Rule of Law? (2) How did it evolve in the United States and Western European democracies, and (3) Given the current circumstances of the rising threat of radical political Islam, what measures need to be developed at the regional and global levels to deal with terrorism?

Police power of the government is an expression of civil authority, i.e., the state's ability to control, regulate, or prohibit non-criminal behavior. ${ }^{5}$

\footnotetext{
${ }^{1}$ Markus D. Dubber, the Police Power, Patriarchy and the Foundation of American GOVERnMENT 13 (New York: Columbia University Press 2005).

${ }^{2} \mathrm{Ibid}$, at 211.

${ }^{3} \mathrm{Ibid}$, at 11 .

${ }^{4}$ Ibid.

${ }^{5}$ Ibid.
} 
The doctrine of state "police power" was adopted in early colonial America from firmly established English common law principles mandating the limitation of private rights when needed for the protection of the common good. It was one of the powers reserved by the states with the adoption of the United States' Federal Constitution and was limited only by the Constitution's Supremacy Clause - which mandates ascendency of federal law in matters, delegated to the federal government-and the individual rights protected in the subsequent Amendments ${ }^{6}$. The application of police power has traditionally implied a capacity to: (1) endorse safety, the public health, morals, or and the general well-being of the community; (2) enact and enforce laws for the promotion of the general welfare; (3) regulate private rights in the public interest; and (4) extend measures to all great public needs ${ }^{7}$.

The comparative literature on the police is still in its infancy. Moreover, with one or two exceptions, it tends to be narrowly descriptive. Indeed, the bulk of comparative material on the police is in the form of reference books, surveys of features of contemporary systems. Such works are valuable, providing useful facts on foreign police systems, but they need to be quickly succeeded by analytical field or operational research, and case studies ${ }^{8}$. The other visible group of comparative writings deals with the police and politics. Apart from Coatman's Police (1959) and Bramstedt's Dictatorship and Political Police (1945), these works are more polemical than insightful, concerned with alleged abuses of police power, rather than the police role in nation building. Often they do not focus so much on the necessary and best police practices in democratic society or transition from dictatorship to democracy which value human rights, and building civil society ${ }^{9}$.

The great problem concerning comparative and historical work on the police is why outstanding initial scholarship did not generate continuing interest. My current research is an attempt to fill this gap, drawing from the great classics of Raymond Fosdick's European Police Systems of 1915, and his American Police Systems of 1920-1969, and Bruce Smith's Police Systems in the United States (1940). The aforementioned seminal works are comparative in the international sense, appropriate for tracing evolutionary changes, precise and careful conceptually, persistent in providing

\footnotetext{
${ }^{6}$ David Schultz, John R. Vile, and Michelle DeardorfF, Constitutional LaW in CONTEMPORARy America, Civil Rights AND Liberties 803 (Volume 2, Oxford: Oxford University Press 2011).

${ }^{7}$ David H. Bayley, Police Function, Structure, and Control in Western Europe and North America: Comparative and Historical Studies, 1 CRIME AND JUSTICE 109-143 (1979).

${ }^{8}$ Ibid.

${ }^{9}$ Ibid.
} 
explanations, and pointed in making recommendations. They set a standard that has yet to be approached ${ }^{10}$.

David H. Bayley's seminal work on Police Function, Structure, and Control in Western Europe and North America, Comparative and Historical Studies (1979) is a serious attempt to shed light on the differences among Western democracies in the police practice and involvement in politics in Western Europe and North America ${ }^{11}$. Bayley's work provided the following comparisons in terms of the latitude of the police practices. $\mathrm{He}$ argued that police organizations in Western democracies are not confined only to protecting life and property and enforcing the law, but also, as political players. Various well-ordered but extensive classification forms have been suggested to cover the range of police activities. None of these schemes does justice to the fruitfulness or the needed productivity of police work in the political system ${ }^{12}$. Bayley presented an exhaustive list of police functions, specifying at least one country where each is performed: (1) protecting life and property (US); (2) enforcing the criminal law (Britain); (3) investigating criminal offenses (France); (4) patrolling public places (Germany); (5) advising about crime prevention (Canada); (6) conducting prosecutions (Britain); (7) sentencing for minor offenses (Germany); (8) maintaining order and decorum in public places by directing, interrupting, and warning (US); (9) guarding persons and facilities (France); (10) regulating traffic (Norway); (11) controlling crowds (Germany); (12) regulating and suppressing vice (US); (13) counseling juveniles (Netherlands); (14) gathering information about political and social life (France); (15) monitoring elections (Italy); (16) conducting counterespionage (France); (17) issuing ordinances (Germany); (18) inspecting premises (Germany); (19) issuing permits and licenses (Britain); (20) serving summonses (Norway); (21) supervising jails (Norway); (22) impounding animals and lost property (Britain); (23) advising members of the public and referring them to other agencies (Scotland); (24) caring for the incapacitated (US); (25) promoting community crime-prevention activities (Scotland); and (26) participating in policy councils of government (France). ${ }^{13}$

Bayley defines government police agents as a group of officers authorized in the name of territorial communities to utilize force within the community to handle whatever needed to maintain internal security. This

\footnotetext{
${ }^{10} \mathrm{Ibid}$.

${ }^{11}$ Ibid.

${ }^{12} \mathrm{Ibid}$.

${ }^{13} \mathrm{Ibid}$.
} 
origination ties police to government and politics in their most common contemporary form, namely, with a territorial mandate; it excludes armies, except when they use force domestically; it excludes private regulatory forces because they are not authorized in the name of the community; and it also excludes persons whose enforcement responsibilities are restricted to specific portions of the law; finally, it does not tie policing to enforcement of law. ${ }^{14}$

\section{The Rule of LaW \& Policing Challenges in Western Democracies AFTER 9/11/2001}

\section{A. In the USA}

In modern constitutional Law, the "rule of law" translates into the principles of law-abiding governmental powers, independent courts, transparency of legislation, and judicial review of the constitutionality of laws and other norms of lower order ${ }^{15}$. Certainly, police overreach is nothing new in the United States and Western democracies. The American Founders wrote the Second Amendment right to bear arms specifically to assuage concern over the potential tyranny of government ${ }^{16}$. The Founders added the Fourth Amendment prohibiting unreasonable search and seizure to further limit government/police power ${ }^{17}$.

After the 9/11/2001 attack on the World Trade Center by radical Islamists and the establishment of the Department of Homeland Security (DHS), the US police and security agencies abuse of power, restricting civil liberties and involvements in internal politics at the national level (federal level) became obvious. Likewise, the police involvement in internal politics of the states is well documented in the literature. Kami C. Simmons seminal work "The Politics of Policing: Ensuring Stakeholder Collaboration In The Federal Reform of Local Law Enforcement" (2008) documents this involvement ${ }^{18}$. Simmons argued that police involvement in internal politics and misconduct continues to be a troubling phenomenon in American

\footnotetext{
${ }^{14}$ Ibid.

${ }^{15}$ Ibrahim Shihata, Complementary Reform, Essays on Legal, Judicial and Other Institutional Reforms Supported by the World Bank, Kluwer Law International 5, (Hague/London/Boston, 1997).

${ }^{16}$ Anna Stolley Persky, Policing The Police, Several Jurisdictions Are Reviewing the Way Law Enforcement Interacts with the Community, 30(5) WASHINGTON LAWYER 32, (2016) (The Official Magazine of the District of Colombia Bar).

${ }^{17}$ Kami Chavis Simmons, The Politics of Policing: Ensuring Stakeholder Collaboration in the Federal Reform of Local Law Enforcement Agencies, 98 J. CRIM. L. \& CRIMINOLOGY 489 (20072008), available at http://scholarlycommons.law.northwestern.edu/jclc.

${ }^{18}$ The Police Power, Patriarchy and the Foundations of American Government, at 211.
} 
society, and it is clear that remedial measures must engage law enforcement agencies to effectively address institutional policies that cultivate or tolerate police misconduct. Where traditional remedies have failed to engender widespread systemic reform, the federal government, police unions, and community members must learn to collaborate in order to develop lasting institutional reforms of the nation's law enforcement agencies.

Paul Schwartzman, staff writer of the Washington Post, argued that in the months after the 9/11 terrorist attacks, New Yorkers venerated the city's police force, wearing NYPD baseball caps and T-shirts, stopping to hug officers on street corners and delivering food and flowers to their precincts. A poll five month after the 2001 attacks found that $76 \%$ of New Yorkers approved of the department's performance. Even among Black New Yorkers - a population with a historically tenuous relationship with cops-the Quinnipiac University survey showed a favorable rating of $56 \%{ }^{19}$. But more than a decade later, New York police are the target of fury, much of it triggered by a grand jury's recent failure to indict an officer in the chokehold death of Eric Garner. The ruling led an assassin from Maryland to execute two police officers in their patrol car as they were parked outside a housing project in Brooklyn. "The Cops are too aggressive, no matter what, they feel like they're above the Law and nothing ever happened to them." That kind of rancor grew out of two decades of aggressive police tactics in the form of "stop and frisk" in which officers routinely detained hundreds of thousands of New Yorkers - most of them African American and Latino Men. In 2013, a federal judge described the tactic as a form of racial profiling and ruled that it violated minorities constitutional rights. ${ }^{20}$ Another interference in politics and misconduct came recently public when a federal security agency, the Central Intelligence Agency (CIA) lied to the United States Congress (Senate Select Committee on Intelligence, 2007) on using a coercive interrogation program. A program which the CIA lobbied the Justice Department, President George W. Bush, Vice President Dick Cheney, Attorney General John Asheroft, White House Counsel Alberto Gonzales, Defense Secretary Donald Rumsfeld, national security adviser Condoleezza Rice to approve ${ }^{21}$. Law professor David Cole described the aforementioned CIA's interference in politics and misconduct of deceiving

\footnotetext{
${ }^{19}$ Ibid.

${ }^{20}$ Paul Schartzman, Rancor Aimed at NYPD Lingers, WASHINGTON PosT, Dec. 25, 2014, at A1 and A6.

${ }^{21}$ Greg Miller and Adam Goldman, Report Charts CIA Prisons' Rise, Fall, Washington Post, A1 and A16.
} 
the United States congress as "too disturbing". 22

In January 15, 2015, Carol Leonnig, argued that

the United States Secret Service has to remove four of its senior leaders while two others are retiring because in the last several years the federal security agency came under criticism by law makers and administration officials, who say it has fostered a culture of distrust between agency leaders and its rank, and file and made poor decisions that helped erode the quality of this once elite agency ${ }^{23}$.

\section{B. In France}

In the aftermath of the 9/11 bombings of the Twin Towers of the World Trade Center in the United States, France has increased stricter security measures and restricted some civil liberties. Excessive use of force, racial profiling and sensitivity to communities are currently important issues not only to the police but to the public in general. Likewise, police ethics, violating civil liberties and involvement in politics are other challenges. Jean Claude Salomon of the University René Descartes Paris V, crime analyst, security consultant, and former Attaché de Mission IHESI (French Ministry of Interior), argued that, in 1986, a police code of ethics (Code de Déontologie de la Police Nationale) was introduced in France ${ }^{24}$. This was one of the police reform policies introduced by the new socialist government that came to power after the 1981 presidential election ${ }^{25}$. Since then, a number of events and changes have occurred, impacting on the implementation and use of the police code of ethics. The socialist party lost power, especially after the 2002 presidential election. A breakdown of the major police union federation which was left of center and partly responsible for the introduction of the code of ethics resulted in a weakening of police unions in general and a shift towards the right of those remaining. Immigration became a major political issue beginning in the early 1990 ' $\mathrm{s}^{26}$. In March 2015, France's Government pressed a surveillance bill that would give the nation's intelligence services legal backing to vacuum up metadata in hopes of preventing imminent terrorist attacks ${ }^{27}$. The measure has prompted an outcry from privacy advocates, human rights groups and the

\footnotetext{
${ }^{22}$ Ibid.

${ }^{23}$ Carol D. Leonnig, Secret Service to Remove Four Senior Leaders, WASHIngton Post, A1 and A6.

${ }^{24}$ Jean Claude Salomon, Lecture on Police Ethics in France: A Twenty-one Years Overview, 2005,

(University Rene' Descartes Paris V, Crime Analyst, Visiting Professor at Sam Houston State

University).

${ }^{25} \mathrm{Ibid}$.

${ }^{26} \mathrm{Ibid}$.

${ }^{27}$ Editorial, Franc's Government Pressed A. Surveillance Bill, WAshington Post, Mar. 20, 2015, at A8.
} 
bar association $^{28}$.

\section{In England}

Recent events in the UK illustrate the difficulties of reconciling police ethics and the general trend towards increased security concerns on the part of governments and their police forces ${ }^{29}$. Lord Macdonald, a former director of public prosecutions, said that "traditional ideals" had been sacrificed in the push against terrorism, and a balance had to be drawn between security and freedom. We want to protect our constitution, we need to protect our way of life, and we need to get this balance right. Lord Macdonald argued that there had been an element of over-reaction, meaning British institutions became a "symbol of hypocrisy" around the world.

I think there's a wide feeling about that across political parties-across political ideologies - and this review has been an attempt to redress that ${ }^{30}$. It's always been of critical importance that we don't, in trying to respond to these threats, give up the things that the terrorists would like to take from us. In other words we don't want to give up the battle without a shot being fired. We want to protect our constitution, we need to protect our way of life, and we need to get this balance right, and I think that is what the review has been trying to achieve ${ }^{31}$.

\section{In Germany}

Nicholas Kulish argued that Germans condemn the police use of spyware. A group that calls itself the Chaos Computer Club pressed a public uproar here recently when it discovered that German state investigators were using spying software capable of turning a computer's webcam and microphone into a sophisticated surveillance device ${ }^{32}$. The club, a German hacking organization, announced last Saturday it had analyzed the hard drives of people who had been investigated and discovered that they were infected with a Trojan horse program that gave the police the ability to log keystrokes, capture screenshots and activate cameras and microphones. The software exceeded the powers prescribed to the police by Germany's Federal Constitutional Court ${ }^{33}$. Now Germans are beginning to recognize that this is a core problem of all people, said Bernd Schlömer, the vice

\footnotetext{
${ }^{28}$ Ibid.

${ }^{29}$ Lord Macdonald, The U.K. Over-Reacted after 9/11, BBC NEws, 2002.

${ }^{30} \mathrm{Ibid}$.

${ }^{31}$ Ibid.

${ }^{32}$ Nicholas Kulish, German Police Arrest Terror Suspects. (September 27, 2008), http://www.nytimes.com/2008/09/27/world/europe/27germany.html.

${ }^{33}$ Ibid.
} 
chairman of Germany's Pirate Party, a new party that recently won $8.9 \%$ of the vote in Berlin's state elections and emphasizes Internet freedom and online privacy issues. He compared the awakening toward the significance of online privacy to the growing consciousness of environmental problems in the 1960s and $1970 \mathrm{~s}^{34}$. In 2007, Germany's Interior Ministry announced that it had developed software that could scan the hard drives of terrorism suspects. The Federal Constitutional Court responded the next year with a ruling that limited such incursions and guaranteed "confidentiality and integrity in information technology systems." Federal investigators said that they were not using this software, but several states, including Lower Saxony and Baden-Württemberg admitted that they had employed it $^{35}$. Colby Mangels raises the question whether the European Union security landscape post $9 / 11$ is necessary protection or unjustified expansion of a security regime? ${ }^{36} \mathrm{He}$ argued that

Following the attacks of 9/11, an unprecedented expansion of the EU-level security capabilities took place within a relatively short amount of time (approximately 2002-2006). ${ }^{37}$

This change reflected long-standing desires of many member-states, as well as EU officials to further utilize the potential of the EU as a basis for counter-terrorism and crime prevention through data-sharing agreements, as well as further streamlining the justice systems of respective memberstates $^{38}$. The events of $9 / 11$ provided the necessary consensus within which individual member-states and EU legislators worked to develop and pass legislations and policies which allowed the EU to expand its powers in the counter-terrorism arena. However, the ambiguity and speed with which some of these new laws and institutions were enacted calls for a closer examination of their effectiveness, and how they will impact on civil liberties $^{39}$. The aforementioned clearly indicates that the rule of law in western democracies such as the United States, France, Britain, and Germany is currently confronting serious challenges rising from police abuse of power and misconduct while enforcing the state police powers to confront radical political Islam.

\footnotetext{
${ }^{34}$ Nicholas Kulish, Pirates' Strong Showing in Berlin Elections Surprises Even Them, THE NEW YORK Times, Sep. 19, 2011, at A1.

${ }^{35} \mathrm{Ibid}$.

${ }^{36}$ Colby Mangels, European Union Security Landscape Post-9/11: Necessary Protection or Unjustified Expansion of a Security Regime? ClarEMONT-UC UnDERGRADUATE RESEARCH CONFERENCE ON THE EUROPEAN UNION, Article 4, 3, 7, 2012, at 9-22.

${ }^{37}$ Ibid.

${ }^{38} \mathrm{Ibid}$.

${ }^{39}$ Ibid.
} 


\section{What The U.S. AND EuROPE ShOUld Do to CONFRONT POLITICAL ISLAM \& INTERNATIONAL TERRORISMS}

Any effective efforts to deal with International Terrorism midwife by political Islam should not be led by the United States and the European Union, but under the United Nations. To many Muslims, the sense of injustice in international relations is symbolized by the fate of the Palestinian people, especially the perceived Western-led by the United States use of double standards. Strictly upholding resolutions and international law when it comes to Muslim countries, but not when it involves Israel, is something of which all Muslims are sharply aware and resent. ${ }^{40}$ Chris Patten, while serving as the EU Commissioner of External Relations, stated that

the treatment of Palestinians is one of the major areas of policy where the approach we in America and Europe could abate or exacerbate Arab hostility, and build rather than burn bridges between the West and the whole of the Islamic World. $^{41}$

The fight against terrorism should continue to be conducted by countries cooperating within the United Nations (Counter-Terrorism Committee-CTC) of the Security Councill ${ }^{42}$. The coalition of more than 60 countries should not by under U.S. leadership (Operation Enduring Freedom), but under a joint leadership comprising the five permanent members of the UN Security Council-US, France, Britain, China, and Russia, under the command of the UN Secretary General.

It is very important not to exempt the fight against terrorism led by the United Nations from the obligations imposed by international human rights norms and other relevant rules under international law. Any policy of fighting terrorism that is insensitive to this concern, or even fails completely in this regard, undermines the very notion of what it means to prevail the rule of law ${ }^{43}$. What is more, it encourages sympathy for terrorists and violent attacks on the West, especially in a region of the world, like the Middle East, where people find it very hard to deal with their historical

\footnotetext{
${ }^{40}$ Maurits Berger, Religion and Islam in Contemporary International Relations, No 27, 22, (Netherlands Institute of International Relations, Clingendael Diplomacy Papers, April 2010). ${ }^{41}$ Ibid.

${ }^{42}$ Wolfgang S. Heinz, and Jan-Michael Arend, The International Fight Against Terrorism and the Protection of Human Rights, with Recommendations to the German Government and the Parliament, (German Institute for Human Rights, Berlin, August 2005), at 31-32.

${ }^{43}$ Terry DAVIS-Secretary General of the Council of Europe, Human Rights AND THE Fight against Terrorism, Council of Europe Guidelines 13-20 (Council of Europe Publishing, March 2005).
} 
experience of injustice in the form of colonialism, the continuing conflict between Israel and the Palestinians, as well as the support lent to autocratic and repressive governments by western policies.

United Nations measures against terrorism should conform to human rights international humanitarian law and the right of protection for refugees. Concerning the fight against terrorism, the ability of the United Nations to observe a country's human rights practice by means of so-called monitoring mechanisms should be more developed. The work that the United Nations has done so far in this complex and rapidly changing area must be considered inadequate, especially with regard to its reporting on individual countries. Of course, this work largely depends on the initiatives and the political will of its member states, and that means, it depends on whether and to what degree they are willing to cooperate with the UN to monitor the fight against terrorism critically, and whether they are open to recommendations ${ }^{44}$.

A UN Convention specifically define the act of "terrorism", is needed. After September 11, 2001, the lack of an internationally recognized definition made it easier for governments to denounce their domestic opposition or the independence movements of certain ethnic groups as terrorists $^{45}$. Already in 2002 the European Union managed to agree on a common definition of terrorism in a framework decision. Strongly affected by the terrorist attacks first in the USA and then in Madrid, the EU decided on comprehensive cooperation in the fight against terrorism. This covers the cooperation of the various national intelligence services, as well as that of EUROPOL and EUROJUST. The exchange of data agreed upon is problematic from the point of view of human and fundamental rights, because, among other things, it is not subject to any parliamentary checks and its purpose is not defined clearly enough ${ }^{46}$.

The fight against terrorism has become a top priority for everyone following the terrorist attacks in recent years. These attacks have been perceived as a direct assault on the fundamental values of human rights, democracy and the rule of law which are Western Democracies' shared heritage. Faced by terrorist acts and threats, the temptation for governments and parliaments is to react at once with force, setting aside the legal safeguards which exist in a democratic state. But let us be clear: in crises, such as those brought about by terrorism, respect for human rights is even more important. Any other choice would favor the aims of terrorists and

\footnotetext{
${ }^{44}$ The International Fight Against Terrorism And the Protection of Human Rights, at 13.

${ }^{45} \mathrm{Ibid}$, at 31 .

${ }^{46}$ Ibid.
} 
would undermine the foundations of our society.

Finally, promoting law enforcement, judicial and intelligence cooperation among US, EU, and UN Members generally are needed as well as the following measures: a common list of terrorist groups, a UN arrest warrant, enhanced tools to stem terrorist financing, new measures to strengthen external border controls and improve transport security, these include information-sharing arrangements among police authorities and judicial bodies, treaties on extradition and mutual legal assistance, and accords on container security and airline passenger data ${ }^{47}$.

\section{CONCLUSION}

This research traces the genealogical genesis of the government's police power and the rule of law in four Western democracies political culture-United States, France, England and Germany. The practice of Policing, the Rule of Law, and the current growing needs of extending the state's police power in light of the growing threat of international terrorism midwifes by political Islam are described in the comparative literature in terms of evolutionary changes. Also, drawing from the literature on the development of the government's police power, and the rule of law nurtured by influential thinkers such as Rousseau, Beccaria, Bentham, Vattel, and Smith. Updated and flourished by the last century's scholars such as Coatman, Bramstedt, Fosdick and contemporary scholars such as Dubber, Smith, Bayley, Shihatta, Simmons, Cole, Salomon, Lord Macdonald, Kulish, Mangels, and Patten.

The research findings revealed the growing tendency of police and security agencies abuse of power, restriction of civil liberties, and involvement in internal politics of the four Western democracies, particularly after the 9/11/2001 attack on the World Trade Center in New York by radical Islamists. The study concluded with two plausible recommendations to confront international terrorism. Firstly, by giving the United Nations the leading role of commanding global activities against international terrorism rather than the US, and its European allies-France, England, and Germany. This is because of the Muslims sense of injustice in international relations symbolized by the perceived Western led by the US use of double standards in dealing with the Palestinian-Israeli conflict. And, secondly, by recommending that the UN measures against

\footnotetext{
${ }^{47}$ Kristin ARCHICK, U.S.-E.U. COOPERATION AGAINST TERRORISM, (Congressional Research Services, CRS Report Prepared for Members and Committees of Congress, March 2, 2016), Rs 22030-7-5700, $6-31$.
} 
international terrorism should start by agreeing on a UN convention which specifically defines the act of "terrorism" as an "international crime", rather than "war", and furthermore, that the needed policing and security measures worldwide should conform to human rights international humanitarian law and the right of protection for refugees. 